\title{
Technical Note: Maximising accuracy and minimising cost of a potentiometrically regulated ocean acidification simulation system
}

\author{
C. D. MacLeod ${ }^{1}$, H. L. Doyle ${ }^{2}$, and K. I. Currie ${ }^{2,3}$ \\ ${ }^{1}$ Department of Zoology, University of Otago, Dunedin, New Zealand \\ ${ }^{2}$ Department of Chemistry, University of Otago, Dunedin, New Zealand \\ ${ }^{3}$ National Institute of Water and Atmospheric Research (NIWA), Dunedin, New Zealand \\ Correspondence to: C. D. MacLeod (colin.macleod@postgrad.otago.ac.nz) \\ Received: 17 March 2014 - Published in Biogeosciences Discuss.: 28 May 2014 \\ Revised: 30 October 2014 - Accepted: 14 November 2014 - Published: 5 February 2015
}

\begin{abstract}
This article describes a potentiometric ocean acidification simulation system which automatically regulates $\mathrm{pH}$ through the injection of $100 \% \mathrm{CO}_{2}$ gas into temperaturecontrolled seawater. The system is ideally suited to longterm experimental studies of the effect of acidification on biological processes involving small-bodied $(10-20 \mathrm{~mm}) \mathrm{cal}-$ cifying or non-calcifying organisms. Using hobbyist-grade equipment, the system was constructed for approximately USD 1200 per treatment unit (tank, $\mathrm{pH}$ regulation apparatus, chiller, pump/filter unit). An overall tolerance of $\pm 0.05 \mathrm{pH}_{\mathrm{T}}$ units (SD) was achieved over 90 days in two acidified treatments (7.60 and 7.40) at $12^{\circ} \mathrm{C}$ using glass electrodes calibrated with synthetic seawater buffers, thereby preventing liquid junction error. The performance of the system was validated through the independent calculation of $\mathrm{pH}_{\mathrm{T}}\left(12^{\circ} \mathrm{C}\right)$ using dissolved inorganic carbon and total alkalinity data taken from discrete acidified seawater samples. The system was used to compare the shell growth of the marine gastropod Zeacumantus subcarinatus infected with the trematode parasite Maritrema novaezealandensis with that of uninfected snails at $\mathrm{pH}$ levels of 7.4, 7.6, and 8.1.
\end{abstract}

\section{Introduction}

The carbon dioxide $\left(\mathrm{CO}_{2}\right)$ produced by human activity since 1850 has reduced average surface oceanic $\mathrm{pH}$ from approximately 8.2 to 8.1 , while current $\mathrm{CO}_{2}$ emission projections predict that oceanic $\mathrm{pH}$ will reach $8.06-7.77$ by 2100 and approximately 7.41 by 2300 (IPCC, 2014). The mechanism responsible for this process is the sequestration of atmospheric
$\mathrm{CO}_{2}$ by the global ocean and a subsequent increase in hydrogen ion activity caused by a series of chemical reactions initiated by the dissolution of $\mathrm{CO}_{2}$ into seawater:

$$
\begin{aligned}
& \mathrm{CO}_{2(\mathrm{aq})}+\mathrm{H}_{2} \mathrm{O}_{(\mathrm{l})} \rightleftharpoons \mathrm{H}_{2} \mathrm{CO}_{3(\mathrm{aq})} \\
& \mathrm{H}_{2} \mathrm{CO}_{3(\mathrm{aq})} \rightleftharpoons \mathrm{HCO}_{3(\mathrm{aq})}^{-}+\mathrm{H}_{(\mathrm{aq})}^{+} \\
& \mathrm{HCO}_{3(\mathrm{aq})}^{-} \rightleftharpoons \mathrm{CO}_{3(\mathrm{aq})}^{2-}+\mathrm{H}_{(\mathrm{aq})}^{+} \\
& \mathrm{CO}_{3(\mathrm{aq})}^{2-}+\mathrm{H}_{(\mathrm{aq})}^{+} \rightleftharpoons \mathrm{HCO}_{3(\mathrm{aq})}^{-}
\end{aligned}
$$

where $\mathrm{H}_{2} \mathrm{CO}_{3}$ is carbonic acid and $\mathrm{HCO}_{3}^{-}$and $\mathrm{CO}_{3}^{2-}$ are the bicarbonate and carbonate ions, respectively. The global reduction of ocean $\mathrm{pH}$ has become known as ocean acidification (OA), although the term also refers to changes in the concentration of carbonic acid and bicarbonate and carbonate ions, in addition to increased hydrogen ion activity (Reactions R1-R4).

The altered chemical speciation of seawater caused by OA poses a variety of challenges to all marine species, e.g. the maintenance of intra- and extra-cellular acid-base homeostasis in a more acidic environment (Pörtner et al., 2004) or the synthesis and dissolution of calcium carbonate $\left(\mathrm{CaCO}_{3}\right)$ structures in seawater undersaturated with regard to component ions (Weiner and Dove, 2003). A meta-analysis conducted by Kroeker et al. (2013) showed that OA will likely have a varied yet negative effect on many marine organisms in future, while negative effects on calcifying species found 
in areas of naturally elevated acidity have already been reported (e.g. Gruber et al., 2012). To date, the majority of experimental research into the effects of OA has focussed on single marine species in an attempt to identify those with or without the ability to adapt to acidified conditions within a single generation. The identification of such phenotypic plasticity in response to stressors associated with $\mathrm{OA}$ is vital, as evolutionary adaptation may not occur at a sufficient rate to protect some species from changing marine conditions (Bell and Collins, 2008). However, it is now accepted that OA research must move beyond single-species experiments and begin investigating the effects of combined abiotic factors, such as $\mathrm{pH}$ and temperature (Boyd, 2011), and the potential effects of OA on biological interactions such as competition (Hoffman et al., 2012), predation (Dixon et al., 2010; Allan et al., 2013), and parasitism (MacLeod and Poulin, 2012). This paradigm does not negate the importance of single-species/single-factor experiments but rather broadens the scope of OA research. A thorough investigation of a species' response to novel abiotic stressors should begin with single-factor manipulations and then introduce increasing levels of complexity to fully document potential synergistic reactions between parameters. Given the current rate of ocean acidification $\left(\sim 0.0018 \mathrm{pH}\right.$ units $\mathrm{yr}^{-1}$, Feely et al., 2009), the identification of species and species' interactions that are vulnerable to OA, alone or in combination with other abiotic factors, should be urgently addressed; lab-based simulations will play an important role in achieving this goal (Widdecombe et al., 2010).

This article provides a detailed description of a low-cost, easy set-up OA simulation system that reliably mimics the effects of elevated atmospheric $\mathrm{CO}_{2}$ on seawater chemistry by controlling temperature, salinity, $\mathrm{pH}$, and total alkalinity $\left(A_{\mathrm{T}}\right)$. In addition, we suggest goal tolerances, i.e. the variability around target parameter values expressed as standard deviations, for the control of these parameters: temperature $\left( \pm 0.5^{\circ} \mathrm{C}\right)$, salinity $( \pm 0.6), \mathrm{pH}( \pm 0.05)$, and $A_{\mathrm{T}}$ $\left( \pm 10 \mu \mathrm{mol} \mathrm{kg}{ }^{-1}\right)$. We believe these tolerance values represent realistic and achievable goals for OA simulation systems, as they can be met with relatively inexpensive apparatus and cause minimal changes to calculated carbonate parameters (Table 3 ).

\section{OA simulation systems}

\subsection{Review}

OA simulation systems must be able to reliably manipulate the carbonate chemistry of seawater, which is characterised by seven parameters: (1) temperature $\left({ }^{\circ} \mathrm{C}\right)$; (2) salinity (reported on the Practical Salinity Scale); (3) depth (metres); (4) $\mathrm{pH}$ :

$\mathrm{pH}=-\log \left[\mathrm{H}^{+}\right]$
(5) total alkalinity $\left(A_{\mathrm{T}} \mu \mathrm{mol} \mathrm{kg}{ }^{-1}\right)$ :

$$
\begin{aligned}
& A_{\mathrm{T}}=\left[\mathrm{HCO}_{3}^{-}\right]+2\left[\mathrm{CO}_{3}^{2-}\right]+\left[\mathrm{B}(\mathrm{OH})_{4}^{-}\right]+\left[\mathrm{OH}^{-}\right] \\
& +\left[\mathrm{HPO}_{4}^{2-}\right]+2\left[\mathrm{PO}_{4}^{3-}\right]+\left[\mathrm{SiO}(\mathrm{OH})_{3}^{-}\right]+\left[\mathrm{NH}_{3}\right] \\
& +\left[\mathrm{HS}^{-}\right]-\left[\mathrm{H}^{+}\right]-\left[\mathrm{HSO}_{4}^{-}\right]-[\mathrm{HF}]-\left[\mathrm{H}_{3} \mathrm{PO}_{4}\right] \ldots
\end{aligned}
$$

(6) dissolved inorganic carbon concentration (DIC- $\mu \mathrm{mol} \mathrm{kg}^{-1}$ ):

$\mathrm{DIC}=\left[\mathrm{CO}_{2}\right]+\left[\mathrm{H}_{2} \mathrm{CO}_{3}\right]+\left[\mathrm{HCO}_{3}^{-}\right]+\left[\mathrm{CO}_{3}^{2-}\right]$

(7) partial pressure of seawater $\mathrm{CO}_{2}\left(p \mathrm{CO}_{2}-\mu a t m\right)$ :

$p\left(\mathrm{CO}_{2}\right)=x\left(\mathrm{CO}_{2}\right) P$

where $x\left(\mathrm{CO}_{2}\right)$ represents the mole fraction of $\mathrm{CO}_{2}$ in the gas phase in equilibrium with seawater and $P$ represents the total pressure. For detailed definitions of the analytical parameters used to characterise seawater carbonate chemistry, please see Dickson et al. (2007). Of the seven variables listed above, temperature, salinity, depth (if applicable), and two of the four analytical parameters must be known, in addition to appropriate equilibrium constants, to fully characterise the carbonate chemistry of the modified seawater and quantify variables central to the effects of OA, e.g. saturation states of calcium carbonate polymorphs or concentrations of $\mathrm{HCO}_{3}^{-}$ and $\mathrm{CO}_{3}^{2-}$. Accordingly, one must control salinity, temperature, and two of the four analytical parameters described above to manipulate the carbonate chemistry of seawater in experimental OA simulation systems.

Riebesell et al. (2010) compiled a detailed guide for the standardisation of methodology used in the manipulation and measurement of carbonate chemistry (The Guide to Best Practices for Ocean Acidification Research and Data Reporting). Since the publication of the guide, there have been several published descriptions of OA simulation systems which use a variety of techniques to acidify seawater: gas injection $\left(\mathrm{CO}_{2} / \mathrm{O}_{2} / \mathrm{N}_{2}-\right.$ Bockmon et al. (2013); $100 \%$ $\mathrm{CO}_{2}$ - Wilcox-Freeburg et al., 2013), the addition of $\mathrm{CO}_{2}$ enriched seawater (McGraw et al., 2010), and the addition of $\mathrm{HCl}$ (Riebesell et al., 2000). Despite the many differences between experimental approaches, almost all simulation systems are regulated through the measurement of $\mathrm{pH}$ as a master variable.

Monitoring $\mathrm{pH}$ in an $\mathrm{OA}$ simulation system by the automated spectrophotometric analysis of seawater samples integrated into a software-based regulation system (e.g. McGraw et al., 2010) provides a high degree of precision $( \pm 0.0004$, Carter et al., 2013; Clayton and Byrne, 1993) compared to potentiometric techniques $( \pm 0.002-0.001$, Dickson et al., 2007) and has been used to regulate OA simulation systems with minimal variation around target $\mathrm{pH}$ values $( \pm 0.02$, McGraw et al., 2010). However, spectrophotometric pH regulation can prove extremely expensive, as these systems must be custom-designed (Wilcox-Freeburg et al., 2013). Despite 
the reduced degree of precision, potentiometric measurement of $\mathrm{pH}$ is the central component of most OA simulation systems designed to explore the effects of reduced $\mathrm{pH}$ on biological organisms (Easley and Byrne, 2012). Indeed, in the 2013 special OA issue of the journal Marine Biology (August, Volume 160, Issue 8), 31 out of 32 (97\%) experimental articles used manipulation techniques controlled by, or monitored through, the potentiometric measurement of $\mathrm{pH}$.

The regulation of temperature, salinity, and $A_{\mathrm{T}}$ is often not discussed in detail in the OA literature, despite the central role of these variables in the control of carbonate chemistry. Temperature is typically controlled by actively heating or cooling the acidified seawater to a target value using a variety of commonly available lab equipment, e.g. chiller units, temperature-controlled rooms, or heating coils. Salinity is often monitored but not controlled, as many simulation systems are supplied with seawater from a large reservoir or permanent connection to the ocean or passively controlled through the regular replacement of seawater. The $A_{\mathrm{T}}$ of an OA simulation system can be altered by the biological activity of experimental organisms. Consequently, $A_{\mathrm{T}}$ is often also regulated through the replacement of seawater or with a flow-through system. Possibly as a consequence of the commonplace (temperature) or passive (salinity and $A_{\mathrm{T}}$ ) methods of regulation, tolerances of these parameters are often not reported in OA literature. In the 2013 special OA issue of the journal Marine Biology, 14 studies used temperature, salinity, $\mathrm{pH}$, and $A_{\mathrm{T}}$ to control and describe seawater carbonate chemistry. Six of these studies reported no measure of temperature variance, 8 reported no salinity variance, and 5 reported no $A_{\mathrm{T}}$ variance. In addition, some articles gave parameter tolerances as standard error (SE), with or without the corresponding sample size, making comparisons of tolerance levels between studies difficult. As the measurement of $\mathrm{pH}$ is subject to many sources of uncertainty, the tolerances of temperature, salinity, and $A_{\mathrm{T}}$ should be stated explicitly and clearly in the description of OA simulation systems.

\subsection{Described system}

\subsubsection{Overview}

The described system manipulates the carbonate chemistry of seawater through the pH-controlled injection of $100 \%$ $\mathrm{CO}_{2}$ gas. The use of $\mathrm{pH}$ as a controlling variable and $\mathrm{CO}_{2}$ gas as an acidifying agent has two key advantages over other acidification techniques. First, the addition of $\mathrm{CO}_{2}$ gas more realistically mimics the effects of increased atmospheric $\mathrm{CO}_{2}$ on seawater chemistry than the addition of an acid (Hurd et al., 2009, Schulz et al., 2009). Second, the pH-controlled addition of $\mathrm{CO}_{2}$ gas reduces $\mathrm{pH}$ variation when compared to the injection of gas-air mixes at a fixed rate; the latter can result in unwanted fluctuations in $\mathrm{pH}$ caused by biological activity, changes in temperature, or increases in ambient atmospheric $\mathrm{CO}_{2}$ (Wilcox-Freeburg et al., 2013). In this system, seawa-

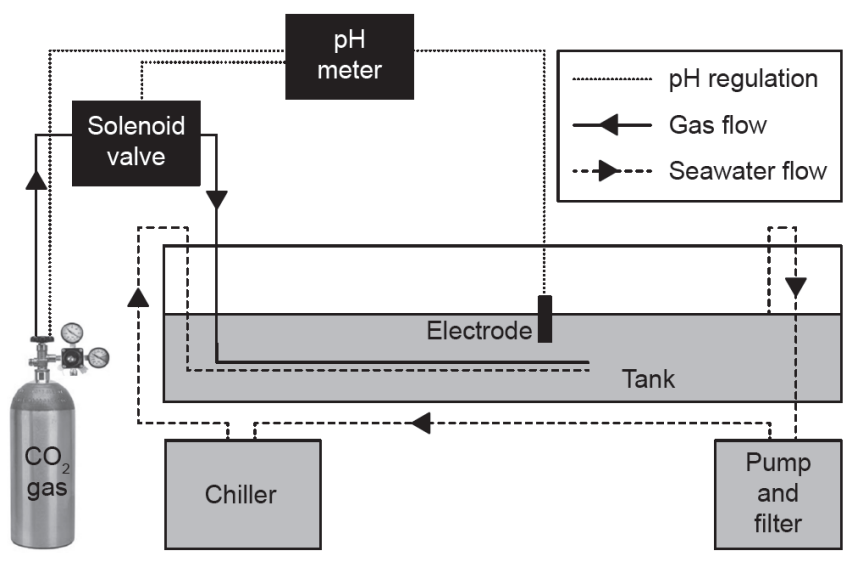

Figure 1. Schematic of one OA simulation unit. Solid lines indicate gas flow, dashed lines indicate seawater flow, and dotted lines indicate electrical connections between components of $\mathrm{pH}$ regulation apparatus.

ter temperature was actively maintained at $12.6 \pm 0.5^{\circ} \mathrm{C}$, while salinity $(31.6 \pm 0.6)$ and $A_{\mathrm{T}}\left(2375 \pm 10 \mu \mathrm{mol} \mathrm{kg}{ }^{-1}\right)$ were passively controlled through the regular replacement of seawater.

\subsubsection{Apparatus}

The described experimental apparatus consists of three identical units (Fig. 1), each capable of independently mimicking the effects of increased atmospheric $\mathrm{CO}_{2}$ on seawater, i.e. elevated $p \mathrm{CO}_{2}$ and DIC and reduced $\mathrm{pH}$. The $\mathrm{pH}$ of culture tank seawater was constantly monitored potentiometrically and automatically regulated through the injection of $100 \%$ food-grade $\mathrm{CO}_{2}$ gas. In each tank, $80 \mathrm{~L}$ of seawater was contained in a $120 \mathrm{~L}$ open-top tank $(870 \mathrm{~mm}(\mathrm{~L}) \times 600 \mathrm{~mm}$ $(\mathrm{W}) \times 295 \mathrm{~mm}(\mathrm{H})$, food-grade low-density polyethylene, Stowers Containment Solutions, NZ). Unamended seawater was supplied by the Portobello Marine Research Station, Dunedin, New Zealand, and was high-pressure filtered through sand prior to use. The unamended seawater had a total alkalinity of $2354 \times 10 \mu \mathrm{mol} \mathrm{kg}{ }^{-1}(n=6)$, and a salinity of $31.5 \pm 0.5 \mathrm{pH}$ in each culture tank was regulated using TUNZE ${ }^{\mathrm{TM}} \mathrm{pH} / \mathrm{CO}_{2}$ controller systems (glass electrodes, $\mathrm{pH}$ meter, solenoid switch unit, and a pressure reducer) connected to $33 \mathrm{~kg}$ gas cylinders containing $100 \%$ food grade $\mathrm{CO}_{2}$ (BOC). The TUNZE ${ }^{\mathrm{TM}}$ system automatically allowed $\mathrm{CO}_{2}$ gas to flow from the pressurised cylinders through the solenoid switch unit into the culture tank when the $\mathrm{pH}$ of acidified seawater rose above target values. Carbon dioxide gas diffused into the acidified seawater through a perforated $4 \mathrm{~mm}$ plastic tube which was wrapped around the water inflow pipe. This allowed for a maximum rate of dispersal of dissolved gas through the culture tank, minimising any $\mathrm{pH}$ gradient relative to the gas input point. To ensure that ambient temperature variations did not alter $\mathrm{pH}\left(\mathrm{TUNZE}^{\mathrm{TM}} \mathrm{pH}\right.$ 
meters have no automatic temperature compensation function), seawater was pumped through a $1 / 5 \mathrm{hp}$ refrigeration unit (Hailea HC-150A) using an aquarium pump-filter system (Aqua One ${ }^{\circledR}$, Aquis700) at a rate of approximately $400 \mathrm{~L} \mathrm{~h}^{-1}$. To minimise changes in salinity and $A_{\mathrm{T}}$ caused by evaporation, calcification, shell dissolution, or respiration, $20 \mathrm{~L}$ of seawater was removed from each tank every $48 \mathrm{~h}$ and gradually $\left(30 \mathrm{Lh}^{-1}\right)$ replaced with unamended seawater. Each culture tank was also aerated with ambient air by an aquarium bubbler (AquaOne 9500), and oxygen saturation (measured daily with a YSI ProODO) was greater than $95 \%$ for the duration of the experimental period.

\subsubsection{Measurement of analytical parameters}

As noted in Easley and Byrne (2012), there are a number of challenges inherent in the potentiometric measurement of $\mathrm{pH}$ : calibration buffers must be of similar ionic strength to samples to avoid liquid junction error (see the Discussion section for a complete description of liquid junction error) (Millero et al., 1993; Waters, 2012); preparing saltwater buffers in the lab can lead to $\mathrm{pH}$ variation due to human error; post-preparation, the $\mathrm{pH}$ of buffers can be altered through contact with ambient atmospheric $\mathrm{CO}_{2}$; electrode function can degrade over time and result in a deviation from the ideal Nernstian slope required to convert volts to $\mathrm{pH}$ units; and all electrodes are subject to a certain degree of drift over time (Dickson et al., 2007).

In the described system, $\mathrm{pH}$ meters were calibrated using homemade saltwater buffers (2-amino-2-hydroxy-1,3propanediol (TRIS) and 2-aminopyridine (AMP)) prepared in accordance with Dickson et al. (2007). Buffer salinity was slightly higher than that of seawater in the culture tanks ( 35 vs. $\sim 32$ ); however, the consequent error was assumed to be less than $0.005 \mathrm{pH}$ units (Dickson et al., 2007). In case of small deviations of buffer $\mathrm{pH}$ caused by human error during preparation, buffers were analysed with an Agilent 8453 spectrophotometer using pure meta-Cresol Purple (mCP) (provided by the laboratory of Professor Robert H. Byrne, University of South Florida) at $25^{\circ} \mathrm{C}$, and $\mathrm{pH}_{\mathrm{T}}$ was calculated from a measured $\mathrm{mCP}$ spectrum using the calibration of Liu et al. (2011). After preparation, saltwater buffers were aliquoted into $100 \mathrm{~mL}$ borosilicate Schott bottles in front of an air pump modified to produce $\mathrm{CO}_{2}$-depleted air, thus minimising the effect of ambient $\mathrm{CO}_{2}$ on buffer $\mathrm{pH}$. With appropriate storage protocols, saltwater buffers prepared in this way have proved stable for up to one year, and subsequent degradation is approximately $0.0005 \mathrm{pH}$ units per year (Nemzer and Dickson, 2005).
Table 1. Average values $( \pm \mathrm{SD}, n=64)$ for $\mathrm{pH}_{\mathrm{T}}$, temperature, and salinity, recorded over a 90-day period in three $\mathrm{pH}$ treatment tanks during the culture of $Z$. subcarinatus.

\begin{tabular}{lrrr}
\hline & $\mathrm{pH}_{\mathrm{T}}$ (Measured) & Temp. $\left({ }^{\circ} \mathrm{C}\right)$ & Salinity \\
\hline 8.1 treatment & $8.09 \pm 0.03$ & $12.5 \pm 0.3$ & $31.7 \pm 0.6$ \\
7.6 treatment & $7.60 \pm 0.03$ & $12.6 \pm 0.6$ & $31.9 \pm 0.6$ \\
7.4 treatment & $7.40 \pm 0.03$ & $12.6 \pm 0.5$ & $31.3 \pm 0.6$ \\
\hline
\end{tabular}

In addition to frequent calibration of $\mathrm{pH}$ electrodes to compensate for drift, TRIS and AMP buffers were used to ensure that all electrode responses were within $0.2-0.3 \%$ of the ideal Nernst value $(0.05916 \mathrm{~V})$ at $25^{\circ} \mathrm{C}$ (Dickson et al., 2007; Millero et al., 1993):

Electrode response $=\mathrm{EMF}_{\mathrm{AMP}}-\mathrm{EMF}_{\mathrm{TRIS}} / \mathrm{pH}_{\mathrm{TRIS}}-\mathrm{pH}_{\mathrm{AMP}}$

where EMF refers to electromotive force, measured in volts. Variability in culture tank $\mathrm{pH}$ was minimised through a two-stage monitoring process. Seawater $\mathrm{pH}$ in each tank was constantly measured with electrodes connected to the $\mathrm{CO}_{2}$ delivery system (TUNZE ${ }^{\mathrm{TM}}$, two-point calibration, $\pm 0.01 \mathrm{pH}$ units). As individual electrodes are prone to drift even with frequent calibration (Dickson et al., 2007), an independent, hand-held $\mathrm{pH}$ meter (Denver Instrument Company AP50, two-point calibration, $\pm 0.002 \mathrm{pH}$ units) was also used to measure culture tank $\mathrm{pH}$ daily. If the Denver $\mathrm{pH}$ meter detected deviations from the target $\mathrm{pH}$, the TUNZE ${ }^{\mathrm{TM}}$ apparatus was adjusted, allowing for centralised control of $\mathrm{pH}$ using the most precise meter available.

The performance of the potentiometric apparatus was also validated with the calculation of $\mathrm{pH}_{\mathrm{T}}\left(12^{\circ} \mathrm{C}\right)$ based on $A_{\mathrm{T}}$ and DIC data taken from culture tank seawater, using SWCO2 Software (Hunter, 2007) and the dissociation constants of Mehrbach et al. (1973) refit by Dickson and Millero (1987). Total alkalinity was measured with a closed-cell potentiometric apparatus, based on the system described by Dickson et al. (2007), while DIC was measured using infrared analyses of $\mathrm{CO}_{2}$ evolved from an acidified sample (AIRICA DIC analyser (Automated Infra Red Inorganic Carbon Analyzer), by MARIANDA). Measurements of $A_{\mathrm{T}}$ and DIC were calibrated using certified reference materials (CRM) from the lab of Professor Andrew Dickson, University of California San Diego. Seawater taken from culture tanks was stored in $1000 \mathrm{~mL}$ borosilicate Schott bottles and fixed with a saturated solution of mercuric chloride prior to $A_{\mathrm{T}}$ and DIC analysis (per recommendations of Riebesell et al., 2010).

\section{Assessment}

\subsection{Carbonate parameters}

Carbonate parameters were monitored throughout a 90day experiment to culture the New Zealand mud snail 
(Zeacumantus subcarinatus), collected from Otago Harbour, Dunedin, New Zealand. During the experimental period, temperature, salinity, and $\mathrm{pH}$ were measured daily (Table 1), while $A_{\mathrm{T}}$ and DIC were analysed from samples taken approximately every 18 days (Table 2). Table 2 also lists other relevant carbonate parameters calculated using DIC and $A_{\mathrm{T}}$ as measured variables.

$\mathrm{pH}_{\mathrm{T}}\left(12{ }^{\circ} \mathrm{C}\right)$, measured both potentiometrically and calculated from DIC and $A_{\mathrm{T}}$ data, varied by $\pm 0.03-0.04$ units (SD) in all three culture tanks over the 90-day period (measured: $7.40 \pm 0.03,7.60 \pm 0.04$; calculated: $7.45 \pm 0.04$, $7.64 \pm 0.04$ ) (Fig. 2). While the calibration of all electrodes occurred weekly, there was very little drift in the electrodes connected to the $\mathrm{CO}_{2}$ regulation apparatus. Temperature, controlled by the chiller units, was also stable across all culture tanks, while salinity and $A_{\mathrm{T}}$ showed minimal variation (Table 1). However, there was a greater relative uncertainty in salinity (approximately $2 \%$ ) than $A_{\mathrm{T}}(<0.5 \%)$ over the experimental period. We assume that this was due to a greater variability in salinity over the entire 90 -day period, detected by more frequent sampling $(n=64)$ compared to $A_{\mathrm{T}}(n=6)$. As expected, DIC (measured) and $p \mathrm{CO}_{2}$ (calculated) increased in all culture tanks after the injection of $\mathrm{CO}_{2}$ gas (Hansen et al., 2013; Campbell and Fourqueran, 2011; Findlay et al., 2008), while $A_{\mathrm{T}}$ remained unchanged in all treatments (Table 2).

Sources of error in our measurement of $\mathrm{pH}$ include the following: spectrophotometric measurement of buffer $\mathrm{pH}$ ( \pm 0.004 , Carter et al., 2013); differences between buffer salinity and seawater salinity $(<0.005$, Dickson et al., 2007); and the potentiometric measurement of seawater $\mathrm{pH}( \pm 0.01-$ $0.002, \mathrm{pH}$ meter specifications).

In addition, while the variability of temperature, salinity, and $A_{\mathrm{T}}$ was relatively minor, measurement errors or incorrect calibrations ("offsets") in these parameters will result in offsets in the calculated parameters central to the study of the effects of OA on marine organisms. Table 3 contains examples of the offsets in calculated carbonate parameters caused by values of uncertainty found in this study. The uncertainty in calculated $\mathrm{pH}$ resulting from uncertainties in measured $A_{\mathrm{T}}$ $\left(10 \mu \mathrm{mol} \mathrm{kg}{ }^{-1}\right)$ and DIC $\left(10 \mu \mathrm{mol} \mathrm{kg}{ }^{-1}\right)$, and uncertainty in the dissociation constants (pK) of $\mathrm{H}_{2} \mathrm{CO}_{3}(0.01)$ and $\mathrm{HCO}_{3}^{-}$ (0.02), gives an uncertainty in calculated $\mathrm{pH}_{\mathrm{T}}$ of approximately $0.05 \mathrm{pH}$ (Dickson and Riley, 1978). Thus, this error estimate in $\mathrm{pH}$ is in good agreement with the difference between our measured and calculated values for seawater $\mathrm{pH}$; measured $\mathrm{pH}$ was between 0.03 and 0.05 lower than calculated $\mathrm{pH}$ in all $\mathrm{pH}$ treatments.

\subsection{Culture of biological organisms}

To investigate the potential interaction of infection stress and stressors associated with OA on the growth of $Z$. subcarinatus, 180 snails (average length, $14.4 \pm 1.3 \mathrm{~mm}$; average mass, $0.22 \pm 0.05 \mathrm{~g}$ ) were distributed evenly between three
$\mathrm{pH}$ treatments: 8.1, 7.6, and 7.4. Of the 60 snails in each treatment, 30 were infected with the marine trematode parasite Maritrema novaezealandensis and 30 had no parasitic infection. Each group of 30 snails was further subdivided into groups of 5 and placed in mesh chambers which allowed the flow-through of seawater. Prior to exposure to acidified seawater, all snails were soaked for $24 \mathrm{~h}$ in a saltwater solution of calcein, a soluble fluorochrome which is incorporated into growing calcified structures and produces a fluorescent band which can be treated as a baseline for subsequent growth ( $\mathrm{Ri}-$ ascos et al., 2007). The snails were maintained in the three $\mathrm{pH}$ treatments for a total of 90 days, although during that time each tank was assigned a particular $\mathrm{pH}$ for only 30 days. During the reassignment of tank $\mathrm{pH}$, snails from the control $(8.1 \mathrm{pH})$ culture tank were first removed and placed in a second aerated container. The now vacant tank was then acidified to $7.6 \mathrm{pH}$ and snails transferred from the tank previously assigned that treatment. This process was repeated for the snails in the $7.4 \mathrm{pH}$ treatment, and the tank originally assigned $7.4 \mathrm{pH}$ was allowed to re-equilibrate with atmospheric $\mathrm{CO}_{2}$ before the "control" snails were replaced. This stepwise changeover removed the potential for tank effect to bias experimental data and reduced any variation in $\mathrm{pH}$ conditions experienced by the snails.

After 90 days, all snails were removed from the culture tanks and the growing edge of their shell imaged under UV light (Leica camera (DFC320) and dissecting scope (MZFL11), 6.4× magnification). New shell growth, visible beyond the fluorescent band, was measured with ImageJ software, and these data were analysed with a two-factor ANOVA (analysis of variance) to test the effects of $\mathrm{pH}$ and infection on shell growth. Analysis of variance showed that there was significantly reduced growth under acidified conditions in infected and uninfected snails (Fig. 3) and that infected snails grew more than uninfected individuals in all $\mathrm{pH}$ treatments. The complete details of this study and the biological interpretations of the findings will be published elsewhere.

\section{Discussion and recommendations}

\subsection{Overview}

This article describes an OA simulation system that maintained temperature, salinity, $\mathrm{pH}$, and $A_{\mathrm{T}}$ within goal tolerances in three $80 \mathrm{~L}$ seawater culture tanks over 90 days. The system was used to culture the New Zealand mud snail, Zeacumantus subcarinatus, to investigate the effects of reduced $\mathrm{pH}$ on individuals infected with the marine trematode M. novaezealandensis relative to uninfected conspecifics. All apparatus used in the construction of the described system was purchased through aquarium suppliers at a cost of approximately USD 3600 , i.e. USD 1200 per unit. 
Table 2. Average values ( $\pm \mathrm{SD}, n=6$ ) for $A_{\mathrm{T}}$ and $\mathrm{DIC}$ (measured) and $\mathrm{pH}_{\mathrm{T}}$ and $p \mathrm{CO}_{2}$ (calculated) recorded over a 90-day period in three $\mathrm{pH}_{\mathrm{T}}$ treatments during the culture of $Z$. subcarinatus.

\begin{tabular}{lrrrr}
\hline & Alkalinity $\left(\mu \mathrm{mol} \mathrm{kg}{ }^{-1}\right)$ & $\mathrm{DIC}\left(\mu \mathrm{mol} \mathrm{kg}{ }^{-1}\right)$ & $\mathrm{pH}_{\mathrm{T}}$ (calculated) & $p \mathrm{CO}_{2}($ calculated $)$ \\
\hline 8.1 treatment & $2361 \pm 10$ & $2138 \pm 11$ & $8.12 \pm 0.03$ & $365 \pm 30$ \\
7.6 treatment & $2389 \pm 7$ & $2351 \pm 16$ & $7.64 \pm 0.04$ & $1304 \pm 115$ \\
7.4 treatment & $2375 \pm 12$ & $2397 \pm 13$ & $7.45 \pm 0.04$ & $1980 \pm 110$ \\
\hline
\end{tabular}

Table 3. A comparison of the offsets resulting in calculated carbonate parameters by offsets or calibration errors in measured variables. The top line shows calculated values for DIC, $p \mathrm{CO}_{2}, \Omega \mathrm{a}$, and $\Omega \mathrm{c}$, calculated based on the average oceanic values for temperature, salinity, $\mathrm{pH}$, and $A_{\mathrm{T}}$ reported in Riebesell et al. (2010). Text in bold indicates the parameter that was varied.

\begin{tabular}{|c|c|c|c|c|c|c|c|c|}
\hline & \multicolumn{4}{|c|}{ Measured parameters } & \multicolumn{4}{|c|}{ Calculated parameters } \\
\hline & Temperature $\left({ }^{\circ} \mathrm{C}\right)$ & Salinity & $\mathrm{pH}_{\mathrm{T}}$ & $A_{\mathrm{T}}\left(\mu \mathrm{mol} \mathrm{kg}{ }^{-1}\right)$ & $\mathrm{DIC}\left(\mu \mathrm{mol} \mathrm{kg}^{-1}\right)$ & $p \mathrm{CO}_{2}(\mu \mathrm{atm})$ & $\Omega \mathrm{a}$ & $\Omega \mathrm{c}$ \\
\hline Oceanic average (2010) & 18.7 & 34.8 & 8.062 & 2305 & 2050 & 384 & 2.83 & 4.38 \\
\hline Temperature $\left( \pm 0.5^{\circ} \mathrm{C}\right)$ & $18.2-19.2$ & 34.8 & 8.062 & 2305 & 2054-2045 & $384-384$ & $2.79-2.88$ & $4.31-4.45$ \\
\hline Salinity $( \pm 0.6)$ & 18.7 & $34.2-35.4$ & 8.062 & 2305 & 2054-2046 & $386-382$ & $2.81-2.86$ & $4.35-4.41$ \\
\hline $\mathrm{pH}_{\mathrm{T}}( \pm 0.05)$ & 18.7 & 34.8 & $8.012-8.112$ & 2305 & 2075-2022 & $440-334$ & $2.58-3.11$ & $3.99-4.80$ \\
\hline$A_{\mathrm{T}}( \pm 10 \mu \mathrm{mol} \mathrm{kg}-1)$ & 18.7 & 34.8 & 8.062 & $2295-2315$ & $2040-2058$ & $381-384$ & $2.83-2.85$ & $4.37-4.41$ \\
\hline Temp. and salinity & $18.2-19.2$ & $34.2-35.4$ & 8.062 & 2305 & $2057-2041$ & $385-381$ & $2.77-2.91$ & $4.29-4.48$ \\
\hline Temp., salinity, and $A_{\mathrm{T}}$ & $18.2-19.2$ & $34.2-35.4$ & 8.062 & $2295-2315$ & $2048-2050$ & $383-382$ & $2.76-2.92$ & $4.27-4.50$ \\
\hline Temp., salinity, $A_{\mathrm{T}}$, and $\mathrm{pH}_{\mathrm{T}}$ & $18.2-19.2$ & $34.2-35.4$ & $8.012-8.112$ & $2295-2315$ & 2074-2023 & $440-334$ & $2.51-3.19$ & $3.88-4.92$ \\
\hline Liquid junction error $( \pm 0.065 \mathrm{pH})$ & 18.7 & 34.8 & $7.997-8.127$ & 2305 & 2083-2014 & $458-320$ & $2.51-3.19$ & $3.88-4.93$ \\
\hline
\end{tabular}

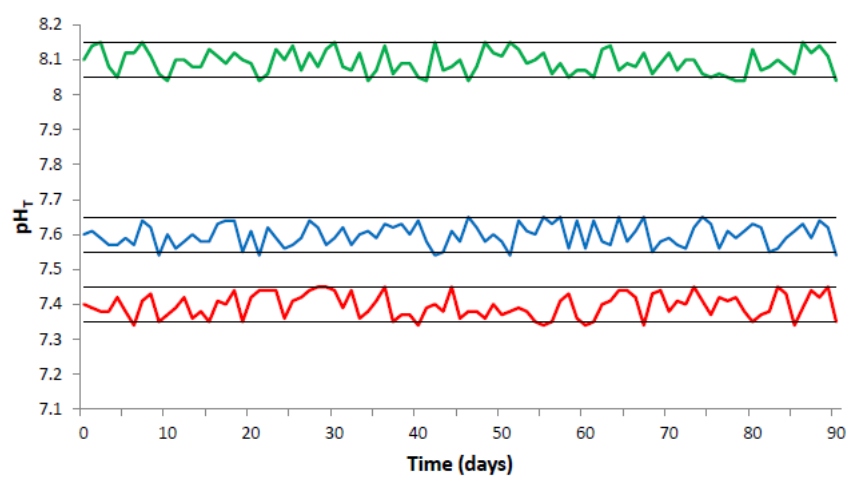

Figure 2. $\mathrm{pH}_{\mathrm{T}}$ recorded over the course of a 90-day experiment in which snails were maintained in three culture tanks: 8.1 (green), 7.6 (blue), 7.4 (red) $\mathrm{pH}_{\mathrm{T}}$. Coloured lines represent $\mathrm{pH}_{\mathrm{T}}$ data recorded on Denver AP50 hand-held $\mathrm{pH}$ meter, and black lines represent \pm 0.05 error around target $\mathrm{pH}_{\mathrm{T}}$ values.

The design of OA simulation systems is under constant development and review (e.g. Findlay et al., 2008; McGraw et al., 2010; Wilcox-Freeburg et al., 2013). The system described here improves the tolerance and repeatability of the potentiometric measurement and regulation of $\mathrm{pH}$ in an $\mathrm{OA}$ simulation system by (a) using two synthetic seawater buffers to calibrate glass electrodes and report $\mathrm{pH}$ on the total hydrogen ion scale $\left(\mathrm{pH}_{\mathrm{T}}\right)$ and (b) measuring two additional, non$\mathrm{pH}$, carbonate parameters to independently validate $\mathrm{pH}$ and monitor changes to seawater chemistry caused by the culture of calcifying organisms. This article also includes an evaluation of offsets in calculated carbonate parameters caused by

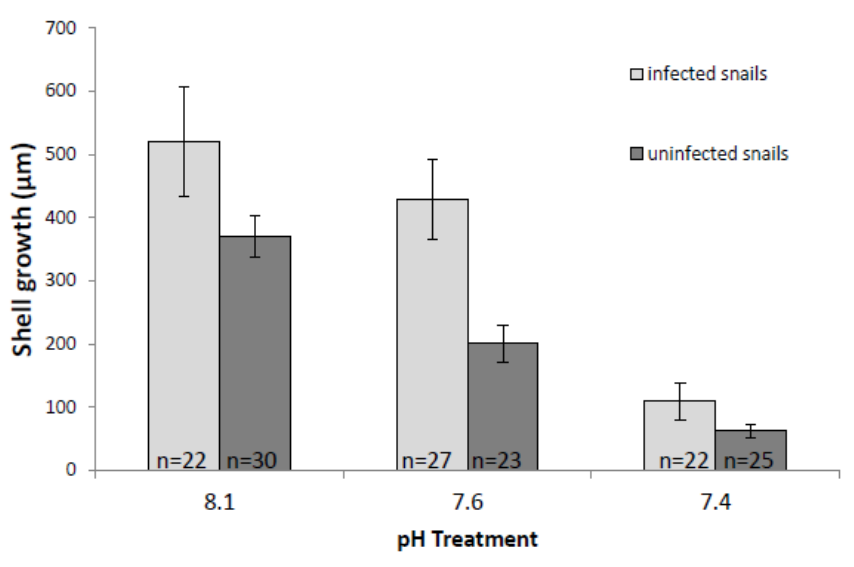

Figure 3. Average shell growth ( \pm SE, sample size as indicated) of infected and uninfected snails in three $\mathrm{pH}$ treatment: 7.4, 7.6, 8.1.

potential offsets and calibration errors in our measurement of temperature, salinity, $\mathrm{pH}_{\mathrm{T}}$, and $A_{\mathrm{T}}$ (Table 3 ). We recommend that this type of assessment is carried out by all researchers working with OA simulation systems.

\subsection{Calibration buffers}

To date, the most commonly used buffers for the calibration of electrodes used in OA simulation systems are defined by the National Bureau of Standards (NBS), now known as the National Institute of Standards and Technology (NIST), and report $\mathrm{pH}$ on the NBS scale $\left(\mathrm{pH}_{\mathrm{NBS}}\right)$. NBS buffers are inexpensive, commonly available in most labs, and have $\mathrm{pH}$ values which are typically pre-programmed into $\mathrm{pH}$ meters 
to facilitate ease of electrode calibration. In the 2013 special OA issue of the journal Marine Biology, 18 out of $32(56 \%)$ experimental articles used these buffers and reported $\mathrm{pH}$ on the NBS scale. However, NBS/NIST buffers have a low ionic strength compared to seawater $(0.1$ vs. $0.7 \mathrm{M}$, Waters, 2012; Hurd et al., 2009) and are not recommended for the measurement of seawater $\mathrm{pH}$ (Zeebe and Gladrow, 2001; Dickson, 1984; Millero, 1986).

When measuring $\mathrm{pH}$ with potentiometric apparatus, the use of calibration buffers with a different ionic strength from sampled media leads to an error based on a fundamental assumption of potentiometric theory, i.e. that the difference in electric potential between the electrode solution and buffer solution is the same as that between the electrode solution and sample solution (Covington, 1985). This error is referred to as liquid junction error and has been discussed in several articles describing the potentiometric measurement of pH (Dickson et al., 2007; Illingworth, 1981; Easley and Byrne, 2012). The pH scale is essentially a quantification of the difference in electric potential between an ion-selective electrode and a sample solution. If the difference in ionic strength between the calibration buffer and sample is great, the electrode will not accurately report the difference in electric potential or provide repeatable measurements (Zeebe and Gladrow, 2001; Wedborg et al., 2009). Liquid junction error has been reported to cause uncertainties of $\pm 0.01-0.14$ units in the measurement of seawater $\mathrm{pH}$ when using electrodes calibrated with low ionic strength buffers (Dickson, 1993; Easley and Byrne, 2012).The use of NBS buffers not only compromises the repeatability of potentiometrically regulated OA simulation experiments, this error is also propagated through calculations of other important seawater characteristics commonly reported in the OA literature, e.g. the saturation states of aragonite $(\Omega \mathrm{a})$ and calcite $(\Omega \mathrm{c})$. If we apply an error of $\pm 0.065 \mathrm{pH}$ units (the median of reported liquid junction error values) to $\Omega \mathrm{a}$ and $\Omega \mathrm{c}$ in the software program SWCO2, we generate errors of 19 and $15 \%$ respectively (Table. 3). The saturation states of aragonite and calcite are particularly vulnerable to this degree of error, as the current range of these variables is 1.2-5.4 ( $\Omega \mathrm{a})$ and 1.9-9.2 $(\Omega \mathrm{c})$ (Riebesell et al., 2010), and $\Omega$ values less than 1.0 , commonly achieved in OA simulation systems, indicate that the dissolution of these $\mathrm{CaCO}_{3}$ polymorphs is thermodynamically favoured (Andersson et al., 2007). This type of error could prevent the correct interpretation of data sets generated in OA experimental studies, as they may indicate a dissolution of calcified structures at saturation states greater than 1.0 .

An additional consideration when reporting data generated by an OA simulation system is the choice of $\mathrm{pH}$ scale. Measurement of seawater $\mathrm{pH}$ can be reported on three scales: the free proton scale $\left(\mathrm{pH}_{\mathrm{F}}\right)$, the total hydrogen ion scale $\left(\mathrm{pH}_{\mathrm{T}}\right)$, and the seawater scale $\left(\mathrm{pH}_{\mathrm{SWS}}\right)$. There has been considerable debate over which scale is the most appropriate for reporting seawater $\mathrm{pH}$ in $\mathrm{OA}$ experiments (e.g. Waters and Millero,
2013), although the total hydrogen ion scale $\left(\mathrm{pH}_{\mathrm{T}}\right)$ is most commonly reported in published data. In the 2013 special OA issue of the journal Marine Biology, $\mathrm{pH}_{\mathrm{T}}$ was reported in 14 out of $32(44 \%)$ of experimental articles, while $\mathrm{pH}_{\mathrm{F}}$ and $\mathrm{pH}_{\text {Sws }}$ were not used at all. One reason for this trend is that $\mathrm{pH}_{\mathrm{T}}$ is generated directly by $\mathrm{pH}$ meters calibrated with saltwater buffers without additional calculation or conversion, as with the free proton and seawater scales. With the increasing availability of these buffers and the importance of establishing comparability between data sets, it seems appropriate that $\mathrm{pH}_{\mathrm{T}}$ should be adopted as the default scale in OA research.

\subsection{DIC and $A_{\mathrm{T}}$ analysis}

Throughout the 90-day trial of this system, seawater samples were periodically taken from each culture tank and used to measure $A_{\mathrm{T}}$ and DIC. The primary purpose of this analysis was to validate the performance of the described system, with respect to the regulation of $\mathrm{pH}$, by using DIC and $A_{\mathrm{T}}$ data to independently calculate the $\mathrm{pH}$ of culture tank seawater using the SWCO2 software. As previously discussed, the calculated $\mathrm{pH}$ was in good agreement with the potentiometrically measured $\mathrm{pH}$, and it is advisable that this additional validation process should be standard procedure after the initial construction of a potentiometrically regulated $\mathrm{OA}$ simulation system. A secondary function of measuring $A_{\mathrm{T}}$ and DIC is the identification of alterations to seawater chemistry caused by the culture of calcifying organisms in acidified seawater. As discussed in Hurd et al. (2009), the addition of $100 \% \mathrm{CO}_{2}$ to seawater is expected to cause an increase in DIC but not affect $A_{\mathrm{T}}$. However, the culture of marine organisms in OA simulation systems can alter the concentration of carbon species in seawater through photosynthesis (decreased $\mathrm{CO}_{2}$ ), respiration (increased $\mathrm{CO}_{2}$ ), or dissolution of calcified structures (increased $\mathrm{HCO}_{3}^{-}$). During an earlier trial of this system, when acidified treatments were 7.1 and $7.4 \mathrm{pH}_{\mathrm{T}}\left(12^{\circ} \mathrm{C}\right), A_{\mathrm{T}}$ greatly exceeded the expected value of $\sim 2300 \mu \mathrm{mol} \mathrm{kg}{ }^{-1}\left(2938.04 \pm 1.29 \mu \mathrm{mol} \mathrm{kg}^{-1}(7.1 \mathrm{pH})\right.$, $\left.2564.16 \pm 3.50 \mu \mathrm{mol} \mathrm{kg}^{-1}(7.4 \mathrm{pH})\right)$ and DIC was also unusually high compared to data generated by other systems that used $\mathrm{CO}_{2}$ gas to reduce $\mathrm{pH}\left(3098.54 \pm 5.14 \mu \mathrm{mol} \mathrm{kg} \mathrm{kg}^{-1}\right.$ $(7.1 \mathrm{pH})$ and $\left.2614.34 \pm 2.61 \mu \mathrm{mol} \mathrm{kg}^{-1}(7.4 \mathrm{pH})\right)$. We assumed that the observed changes in seawater chemistry were caused by the release of $\mathrm{HCO}_{3}^{-}$through the dissolution of calcified structures, as the snail shells had visibly dissolved, and therefore we increased the replacement rate of seawa-

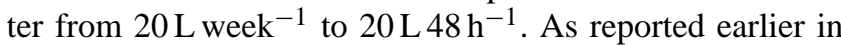
this paper, further analysis of $A_{\mathrm{T}}$ and DIC showed that these parameters had returned to expected levels, supporting the assumption that the dissolution of calcified structures had altered seawater chemistry. It is important to note that the replacement rate of seawater used in this simulation system may be specific to the size and number of snails in culture and the volume of the culture tanks. These observations illustrate the importance of measuring both $A_{\mathrm{T}}$ and DIC during 
the culture of calcifying organisms in acidified seawater, especially in closed or partially closed systems. If only DIC had been measured and $A_{\mathrm{T}}$ assumed to be constant, elevated DIC could have been solely attributed to the addition of $\mathrm{CO}_{2}$ and could have resulted in the introduction of an unknown, additional abiotic factor to the experimental design.

\section{Conclusions}

The described system increases the accessibility of reliable OA simulation apparatus by using relatively inexpensive equipment that is readily available from aquarium suppliers. With careful calibration and the use of appropriate buffers, it is possible to generate high-quality and repeatable data. Incorporating DIC and $A_{\mathrm{T}}$ analysis in the validation of this system also provides a greater degree of reliability with regard to $\mathrm{pH}$ manipulation and a more complete understanding of the complex nature of seawater chemistry. Additional stressors such as temperature, salinity, and UV radiation could also be easily incorporated into experimental design due to the modular design of this system. Consequently, this system will facilitate the increase in research effort required to identify species, and species' interactions, vulnerable to novel stressors associated with $\mathrm{OA}$, alone or in combination with other abiotic factors.

Acknowledgements. This research was supported by funding from the University of Otago Doctoral Scholarship Program (C. D. MacLeod), the University of Otago Research Centre for Oceanography (H. L. Doyle), the National Institute of Water and Atmospheric Research (K. I. Currie and H. L. Doyle), and the Departments of Zoology and Chemistry, University of Otago. The authors also thank Robert Poulin, Andrew Dickson, an anonymous reviewer, and members of the Evolutionary and Ecological Parasitology Research Group, University of Otago, for constructive comments on an earlier draft of this manuscript, and Lisa Bucke, University of Otago, for the preparation of a schematic included in this article.

Edited by: K. Fennel

\section{References}

Allan, B. J. M., Domenici, P., McCormick, M. I., Watson, S., and Munday, P. L.: Elevated $\mathrm{CO}_{2}$ affects predator-prey interactions through altered performance, PLOS ONE, 8, 1-7, doi:10.1371/journal.pone.0058520, 2013.

Andersson, A. J., Bates, N. R., and Mackenzie, F. T.: Dissolution of carbonate sediments under rising $p \mathrm{CO}_{2}$ and ocean acidification: observations from Devil's Hole, Bermuda, Aquat. Geochem., 13, 237-264, doi:10.1007/s10498-007-9018-8, 2007.

Bell, G. and Collins, S.: Adaptation, extinction and global change, Evol. Appl., 1, 3-16, doi:10.1111/j.1752-4571.2007.00011.x, 2008.
Bockmon, E. E., Frieder, C. A., Navarro, M. O., White-Kershek, L. A., and Dickson, A. G.: Technical Note: Controlled experimental aquarium system for multi-stressor investigation of carbonate chemistry, oxygen saturation, and temperature, Biogeosciences, 10, 5967-5975, doi:10.5194/bg-10-5967-2013, 2013.

Boyd, P. W.: Beyond ocean acidification, Nat. Geosci., 4, 273-274, doi:10.1038/ngeo1150, 2011.

Campbell, J. E. and Fourqurean, J. W.: Novel methodology for in situ carbon dioxide enrichment of benthic ecosystems, Limnol. Oceanogr-Meth., 9, 97-109, doi:10.4319/lom.2011.9.97, 2011.

Carter, B. R., Radich, J. A., Doyle, H. L., and Dickson, A. G.: An automated system for spectrophotometric seawater $\mathrm{pH}$ measurements, Limnol. Oceanogr-Meth., 11, 16-27, doi:10.4319/lom.2013.11.16, 2013.

Clayton, T. D. and Byrne, R. H.: Spectrophotometric seawater $\mathrm{pH}$ measurements: total hydrogen ion concentration scale calibration of $m$-cresol purple and at-sea results, Deep-Sea Res., 40, 21152129, doi:10.1016/0967-0637(93)90048-8, 1993.

Covington, A. K., Bates, R. B., and Durst, R. A.: Definition of $\mathrm{pH}$ scales, standard reference values, measurement of $\mathrm{pH}$ and related terminology, Pure Appl. Chem., 57, 531-542, doi:10.1351/pac198557030531, 1985.

Dickson, A. G.: pH scales and proton-transfer reactions in saline media such as sea water, Geochim. Cosmochim. Ac., 48, 22992308, 1984.

Dickson, A. G.: The measurement of sea water pH, Mar. Chem., 44, 131-142, doi:10.1016/0304-4203(93)90198-W, 1993.

Dickson, A. G. and Millero, F. J.: A comparison of the equilibrium constants for the dissociation of carbonic acid in seawater media, Deep-Sea Res., 34, 1733-1743, doi:10.1016/01980149(87)90021-5, 1987.

Dickson, A. G. and Riley, J. P.: The effect of analytical error on the evaluation of the components of the aquatic carbon-dioxide system, Mar. Chem., 6, 77-85, doi:10.1016/0304-4203(78)90008-7, 1978.

Dickson, A. G., Sabine, C. L., and Christian, J. R.: Guide to best practices for ocean $\mathrm{CO}_{2}$ measurements, PICES Special Publication 3, 191, 2007.

Dixson, D. L., Munday, P. L., and Jones, G. P.: Ocean acidification disrupts the innate ability of fish to detect predator olfactory cues, Ecol. Lett., 13, 68-75, doi:10.1111/j.1461-0248.2009.01400.x, 2010.

Easley, R. A. and Byrne, R. H.: Spectrophotometric Calibration of $\mathrm{pH}$ Electrodes in Seawater Using Purified m-Cresol Purple, Environ. Sci. Technol., 46, 5018-5024, doi:10.1021/es300491s, 2012.

Feely, R. A., Doney, S. C., and Cooley, S. R.: Ocean acidification: present conditions and future changes, Oceanogr., 22, 36-47, doi:10.5670/oceanog.2009.95, 2009.

Findlay, H. S., Kendall, M. A., Spicer, J. I., Turley, C., and Widdicombe, S.: Novel microcosm system for investigating the effects of elevated carbon dioxide and temperature on intertidal organisms, Aquat. Biol., 3, 51-62, doi:10.3354/ab00061, 2008.

Gruber, N., Hauri, C., Lachkar, Z., Loher, D., Folicher, T. L., and Plattner, G.: Rapid Progression of Ocean Acidification in the California Current System, Science, 337, 220, doi:10.1126/science.1216773, 2012.

Hansen, T., Gardeler, B., and Matthiessen, B.: Technical Note: Precise quantitative measurements of total dissolved inorganic car- 
bon from small amounts of seawater using a gas chromatographic system, Biogeosciences, 10, 6601-6608, doi:10.5194/bg-106601-2013, 2013.

Hofmann, L. C., Straub, S., and Bischof, K.: Competition between calcifying and noncalcifying temperate marine macroalgae under elevated $\mathrm{CO}_{2}$ levels. Mar. Ecol-Prog. Ser., 464, 89-105, doi:10.3354/meps09892, 2012.

Hunter, K. A. SWCO2, http://neon.otago.ac.nz/research/mfc/ people/keith_hunter/software/swco2, last access: 1 March 2014.

Hurd, C. L., Hepburn, C. D., Currie, K. I., Raven, J. A., and Hunter, K. A.: Testing the effects of ocean acidification on algal metabolism: considerations for experimental designs, J. Phycol., 45, 1236-1251, doi:10.1111/j.1529-8817.2009.00768.x, 2009.

Illingworth, J. A.: A common source of error in $\mathrm{pH}$ measurements, Biochem. J., 195, 259-262, 1981.

IPCC: Climate Change 2014: Impacts, Adaptation, and Vulnerability. Part A: Global and Sectoral Aspects. Contribution of Working Group II to the Fifth Assessment Report of the Intergovernmental Panel on Climate Change, edited by: Field, C. B., Barros, V. R., Dokken, D. J., Mach, K. J., Mastrandrea, M. D., Bilir, T. E., Chatterjee, M., Ebi, K. L., Estrada, Y. O., Genova, R. C., Girma, B., Kissel, E. S., Levy, A. N., MacCracken, S., Mastrandrea, P. R., and White, L. L., Cambridge University Press, Cambridge, United Kingdom and New York, NY, USA, 1132 pp., 2014.

Kroeker, K. J., Kordas, R. L., Crim, R., Hendriks, I. E., Ramajo, L., Sihngh, G. S., Duarte, C. M., and Gattuso, J.: Impacts of ocean acidification on marine organisms: quantifying sensitivities and interaction with warming, Glob. Change Biol., 19, 1884-1889, doi:10.1111/gcb.12179, 2013.

Liu, X., Patsavas, M. C., and Byrne, R. H.: Purification and Characterization of meta-Cresol Purple for Spectrophotometric Seawater $\mathrm{pH}$ Measurements, Environ. Sci. Technol., 45, 4862-4868, doi:10.1021/es200665d, 2011.

MacLeod, C. D. and Poulin, R.: Host-parasite interactions: a litmus test for ocean acidification?, Trends Parasitol., 28, 365-369, doi:10.1016/j.pt.2012.06.007, 2012.

McGraw, C. M., Cornwall, C. E., Reid, M. R., Currie, K. I., Hepburn, C. D., Boyd, P., Hurd, C. L., and Hunter, K. A.: An automated $\mathrm{pH}$-controlled culture system for laboratory-based ocean acidification experiments, Limnol. Oceanogr-Meth., 8, 686-694, doi:10.1016/j.marchem.2011.04.002, 2010.

Mehrbach, C., Culberson, C. H., Hawley, J. E., and Pytkowicz, R. M.: Measurements of the apparent dissociation constants of carbonic acid in seawater at atmospheric pressure, Limnol. Oceanogr., 18, 897-907, 1973.

Millero, F. J.: The pH of estuarine waters, Limnol. Oceanogr., 31, 839-847, 1986.

Millero, F. J., Zhang, J.-Z., Fiol, S., Sotolongo, S., Roy, R. N., Lee, K., and Mane, S.: The use of buffers to measure the $\mathrm{pH}$ of seawater, Mar. Chem., 44, 143-152, doi:10.1016/03044203(93)90199-X, 1993.

Nemzer, B. V. and Dickson, A. G.: The stability and reproducibility of Tris buffers in synthetic seawater, Mar. Chem., 96, 237-242, doi:10.1016/j.marchem.2005.01.004, 2005.
Pörtner, H. O., Langenbuch, M., and Reipschlager, A.: Biological Impact of Elevated Ocean $\mathrm{CO}_{2}$ Concentrations: Lessons from Animal Physiology and Earth History, J. Oceanogr., 60, 705718, doi:10.1007/s10872-004-5763-0, 2004.

Riascos, J., Guzman, N., Laudien, J., Heilmayer, O, and Oliva, M.: Suitability of three stains to mark shells of Concholepas concholepas (Gastropoda) and Mesodesma donacium, J. Shellfish Res., 26, 43-49, doi:10.2983/07308000(2007)26[43:SOTSTM]2.0.CO;2, 2007.

Riebesell, U., Zondervan, I., Rost, B., Tortell, P. D. Zeebe, R. E., and Morel, F. M. M.: Reduced calcification of marine plankton in response to increased atmospheric $\mathrm{CO}_{2}$, Nature, 407, 364-367, doi:10.1038/35030078, 2000.

Riebesell, U., Fabry, V. J., Hansson, L., and Gattuso, J. P.: Guide to best practices for ocean acidification research and data reporting, Luxembourg, Publications Office of the European Union, 260 pp., 2010.

Schulz, K. G., Barcelos e Ramos, J., Zeebe, R. E., and Riebesell, U.: $\mathrm{CO}_{2}$ perturbation experiments: similarities and differences between dissolved inorganic carbon and total alkalinity manipulations, Biogeosciences, 6, 2145-2153, doi:10.5194/bg-6-21452009, 2009.

Waters, J. F.: Measurement of seawater $\mathrm{pH}$ : a theoretical and analytical investigation, PhD Thesis, University of Miami, Miami, FL, 199 pp., 2012.

Waters, J. F. and Millero, F. J.: The free proton concentration scale for seawater $\mathrm{pH}$, Mar. Chem., 149, 8-22, doi:10.1016/j.marchem.2012.11.003, 2013.

Wedborg, M., Turner, D. R., Anderson, L. G., and Dyrssen, D.: Determination of $\mathrm{pH}$, in: Methods of seawater analysis, edited by: Grasshoff, K., Kremling, K., and Ehrhardt, M., New York, Wiley-VCH, 109-125, 2009.

Weiner, S. and Dove, P. M.: An Overview of Biomineralization Processes and the Problem of the Vital Effect, Rev. Mineral Geochem., 54, 1-29, doi:10.2113/0540001, 2003.

Widdecombe, S., Dupont, S., and Thorndyke, M.: Laboratory experiments and benthic mesocosm studies, in: Guide to best practices for ocean acidification research and data reporting, edited by: Riebesell, U., Fabry, V. J., Hansson, L., and Gattuso, J. P., Luxembourg, Publications Office of the European Union, 260 pp., 2010.

Wilcox-Freeburg, E., Rhyne, A., Robinson, W. E., Tlusty, M., Bourque, B., and Hannigan, R. E.: A comparison of two $\mathrm{pH}$-stat carbon dioxide dosing systems for ocean acidification experiments, Limnol. Oceanogr-Meth., 11, 485-494, doi:10.4319/lom.2013.11.485, 2013.

Zeebe, R. E. and Wolf-Gladrow, D.: $\mathrm{CO}_{2}$ in Seawater Equilibrium, Kinetics, Isotopes, Burlington: Elsevier Science, 361 pp., 2001. 